\title{
The Role of Weed Hosts and Tobacco Thrips, Frankliniella fusca, in the Epidemiology of Tomato spotted wilt virus
}

\author{
R. L. Groves, USDA-ARS, Plant Protection Research Unit, Cornell University, Ithaca, NY 14853; J. F. Walgen- \\ bach, North Carolina State University, Department of Entomology, Raleigh, NC 27695; J. W. Moyer, North Caro- \\ lina State University, Department of Plant Pathology, Raleigh, NC 27695; and G. G. Kennedy, North Carolina State \\ University, Department of Entomology, Raleigh, NC 27695
}

\begin{abstract}
Groves, R. L., Walgenbach, J. F., Moyer, J. W., and Kennedy, G. G. 2002. The role of weed hosts and tobacco thrips, Frankliniella fusca, in the epidemiology of Tomato spotted wilt virus. Plant Dis. 86:573-582.

Wild plant species were systematically sampled to characterize reproduction of thrips, the vector of Tomato spotted wilt virus (TSWV), and natural sources TSWV infection. Thrips populations were monitored on 28 common perennial, biennial, and annual plant species over two noncrop seasons at six field locations across North Carolina. Sonchus asper, Stellaria media, and Taraxacum officianale consistently supported the largest populations of immature TSWV vector species. The tobacco thrips, Frankliniella fusca, was the most abundant TSWV vector species collected, comprising over $95 \%$ of vector species in each survey season. Perennial plant species (i.e., Plantago rugelii and Taraxacum officianale) were often only locally abundant, and many annual species (Cerastium vulgatum, Sonchus asper, and Stellaria media) were more widely distributed. Perennial species, including P. rugelii and Rumex crispus, remained TSWV infected for 2 years in a small-plot field test. Where these perennial species are locally abundant, they may serve as important and long-lasting TSWV inoculum sources. In random surveys across 12 locations in North Carolina, TSWV infection was documented by double antibody sandwich enzyme-linked immunosorbent assay in 35 of $72(49 \%)$ common perennial $(\mathrm{N}=10)$, biennial $(\mathrm{N}=4)$, and annual $(\mathrm{N}=21)$ plant species across 18 plant families. Estimated rates of TSWV infection were highest in Cerastium vulgatum (4.2\%), Lactuca scariola (1.3\%), Molluga verticillata (4.3\%), Plantago rugelii (3.4\%), Ranunculus sardous (3.6\%), Sonchus asper (5.1\%), Stellaria media (1.4\%), and Taraxacum officianale (5.8\%). Nine plant species were determined to be new host recordings for TSWV infection, including Cardamine hirsuta, Eupatorium capillifolium, Geranium carolinianum, Gnaphalium purpureum, Linaria canadense, Molluga verticillata, Pyrrhopappus carolinianus, Raphanus raphanistrum, and Triodanis perfoliata. Our findings document the relative potential of a number of common annual, biennial, and perennial plant species to act as important reproductive sites for $F$. fusca and as acquisition sources of TSWV for spread to susceptible crops.
\end{abstract}

Additional keywords: Frankliniella occidentalis, Thrips tabaci

Tomato spotted wilt virus (TSWV) and other closely related tospoviruses are serious threats to many agricultural, ornamental, and greenhouse crops. TSWV was first recorded in the southeastern United States during the middle to late 1980s $(10,12,16,19,23)$, with the first collections of the western flower thrips, Frankliniella occidentalis (Pergande), following shortly

Corresponding author: R. L. Groves

E-mail: Russell.Groves@maine.edu

Accepted for publication 15 January 2002.

Publication no. D-2002-0326-02R

This article is in the public domain and not copyrightable. It may be freely reprinted with customary crediting of the source. The American Phytopathological Society, 2002. thereafter. In North Carolina, TSWV was first detected in tobacco and tomato in 1988, although infections occurred at very low levels. During the following 6 to 8 years, TSWV incidence remained low and was widely scattered among fields, suggesting that endemic inoculum sources had not yet become established. By 1997, TSWV had occurred in nearly every North Carolina county, with the incidence in some individual fields reaching high levels. Since then, many flue-cured tobacco fields have experienced 30 to $50 \%$ losses, and county-wide incidence of infected plants has averaged 10 to $15 \%$ in Duplin, Onslow, and Pender counties. Although area-wide levels of infection were lower in 2000, some tomato, pepper, and tobacco fields again experienced 25 to $50 \%$ infected plants.
Worldwide, this virus is transmitted by at least eight thrips species $(8,26)$. In eastern and central North Carolina, the primary vector of TSWV is the tobacco thrips, Frankliniella fusca (Hinds), although $F$. occidentalis may be locally important, especially in the western Piedmont and mountainous portions of the state (12). Thrips acquire TSWV by feeding on infected plants as larvae, with a subsequent latent period of approximately 3 to 7 days before transmission of the virus to uninfected plants (36), and remain competent vectors for the remainder of their lives. Thus, only those plants that sustain virus infections and serve as suitable reproductive hosts for the vector can be considered important sources for spread of TSWV.

TSWV has an extensive host range including over 600 plant species $(2,3,7,8,20$ 22,24,28,31). Many plants susceptible to TSWV do not support thrips reproduction and are considered a "dead end" for virus spread (11). A more complete understanding of the sources of vector reproduction and TSWV infection is warranted to determine which plant species may serve as both reproductive hosts for vectors and the primary inoculum sources for TSWV spread. The current study was conducted to systematically identify, through field collections, wild plant species supporting both vector reproduction and natural TSWV infection in North Carolina.

\section{MATERIALS AND METHODS}

Field survey of reproducing thrips populations. Whole plants of common wild species were collected monthly from October through May during 1996-97 and 1998-99 to examine the composition and extent of reproducing thrips populations. In the 1996-97 winter season, 20 whole plant samples of 16 to 21 different plant species were collected monthly from the field in Johnston (Jones), Henderson (Mills River) and Wake (Ball) counties in North Carolina (Fig. 1), where TSWV infection in susceptible crops has been observed. Plant identifications were made using a manual for identification of vascular plants (29) and through the assistance of the North Carolina State University, Botanical Herbarium, 
Raleigh. Where possible, 10 plants of each species were collected from the field interior and 10 plants were collected in the field margins. Each plant was cut at the soil surface and placed in a 5.6-liter white, plastic container (Venture Packaging Inc., Monroeville, $\mathrm{OH}$ ) containing a Phaseolus vulgaris pod. Containers were covered with Bugbed 110 (Green Thumb Group, Downers Grove, IL) fine mesh screened lids and placed in environmental chambers maintained at $25^{\circ} \mathrm{C}, 20 \%$ relative humidity (RH), and a photoperiod of 14:10 (L:D) $h$ for $72 \mathrm{~h}$. As the thrips left the desiccating plant, they concentrated on the succulent bean pod. Within 3 days after the plants had fully desiccated, all adult and immature thrips were collected from the bean pods and counted. Thrips collected as adults were placed into 5-dram $(20 \mathrm{ml})$ glass vials containing $70 \%$ ethanol. Those collected as immatures were reared to the adult stage by transferring them to fresh bean pods placed in 474-ml clear plastic cups, which were covered with fine mesh and placed in environmental chambers maintained at $24^{\circ} \mathrm{C}, 65 \% \mathrm{RH}$, and $14: 10$ (L:D) h. All thrips collected were mounted on slides using CMC-10 mounting media (Masters Chemical, Elk Grove, IL) and later identified using a key to the Terebrantia suborder (27). Voucher specimens were deposited in the North Carolina State University insect collection.

Nineteen different plant species were collected monthly at the Wake County site (Ball). These included: Caryophyllaceae: Cerastium vulgatum L. (mouse-ear chickweed), Scleranthus annuus L. (knawel), Stellaria media (L.) Cyrillo; Compositae: Erigeron canadensis L. (horseweed), Gnaphalium obtusifolium L. (sweet everlast- ing), G. purpureum L. (purple cudweed), Hypochaeris radicata L. (cat's ear), Lactuca scariola L. (prickly lettuce), Sonchus asper (L.) Hill (spiny-leaved sow-thistle), Taraxacum officianale F.H. Wigg. (dandelion); Cruciferae: Raphanus raphanistrum L. (wild radish); Fabaceae: Trifolium campestre Schreb. (large hop clover), T. repens L. (white clover); Geraniaceae: Geranium carolinianum L. (Carolina geranium); Labiatae: Lamium amplexicaule L. (henbit); Plantaginaceae: Plantago lanceolata L. (narrow-leaf plantain); Polygonaceae: Rumex acetosella L. (red sorrel), $R$. crispus L. (curly dock); Scrophulariaceae: Linaria canadensis (L.) Dumort. (old-field toadflax). In addition to the 19 aforementioned species, Caryophyllaceae: Agrostemma githago L. (corn cockle) was regularly sampled at the Johnston County site (Jones). At the Henderson County site (Mills River), 16 species were sampled: Stellaria media; Sonchus asper, Taraxacum officianale; Cruciferae: Brassica rapa L. (field mustard), Cardamine hirsuta L. (bittercress), Descurainia pinnata (Walt.) Britt. (tansy mustard), Raphanus raphanistrum; Geranium carolinianum; Lamium amplexicaule; Onagraceae: Oenothera biennis L. (evening primrose); Plantaginaceae: Plantago virginica L. (hoary plantain); Polygonaceae: Polygonum pensylvanicum L. (smartweed), Rumex obtusifolius L. (sour dock); Ranunculaceae: Ranunculus abortivus L. (crowfoot), $R$. parviflorus L. (small-flowered crowfoot); Rosaceae: Fragaria virginiana Duchesne (wild strawberry).

Populations of reproducing thrips on wild plant species were monitored monthly during the winter and spring of 1998-99. Three new experimental sites were sam- pled in 1998-99, including Harnett County (Honeycutt), Johnston County (Fish), and Granville County (Williams), NC, plus the Johnston County site (Jones) originally sampled in the 1996-97 survey (Fig. 1). New experimental sites were examined in the 1998-99 survey as a result of a change in property ownership (Ball) and travel considerations (Mills River). Thrips were removed from plants as described. At each site, up to five plant species were collected monthly. Four plant species-Plantago lanceolata, Rumex crispus, Stellaria media, and Taraxacum officianale-were collected at both Johnston County locations (Fish, Jones) and the Harnett County location (Honeycutt). Monthly collections of Raphanus raphanistrum were unique to the Johnston County location (Fish), S. asper collections were unique to the Honeycutt location in Harnett County, Scleranthus annuus collections were unique to the Jones location in Johnston County. Monthly collections of Plantaginaceae: Plantago rugelii Decne. (Rugel's plantain) and Ranunculaceae: Ranunculus sardous Crantz (short buttercup) were unique to the Granville County location and were the only two plant species monitored at this location during the 1998-99 winter season. Two of the plant species, Plantago lanceolata and Rumex crispus, were selected based on the 199697 survey as plants supporting belowaverage $F$. fusca reproduction, whereas the remaining seven were selected as hosts supporting above-average $F$. fusca reproduction in the same survey. All thrips collected as adults, or collected as immatures and later reared to the adult stage on green bean pods, were counted and identified as described.

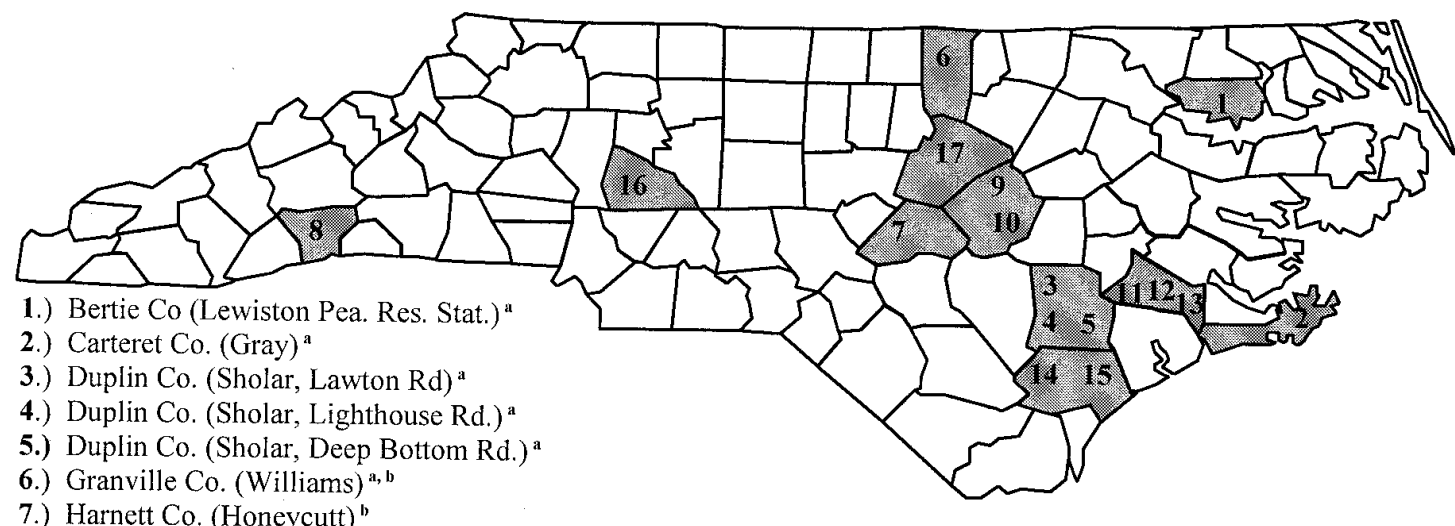

7.) Harnett Co. (Honeycutt)"

8.) Henderson Co. (Mills River) ${ }^{\mathrm{a}, \mathrm{b}}$

9.) Johnston Co. (Fish) "

10.) Johnston Co. (Jones) ${ }^{b}$

11.) Jones Co. (Higgins) ${ }^{a}$

12.) Jones Co. (Meadows) ${ }^{a}$

13.) Jones Co. (Stanley) ${ }^{a}$

${ }^{\mathrm{a}}$ Experimental site for Tomato spotted wilt virus survey.
${ }^{\mathrm{b}}$ Experimental site for Frankliniella fusca survey.

14.) Pender Co. (Sholar, 50S) ${ }^{a}$

15.) Pender Co. (Hollingsworth) ${ }^{a}$

16.) Rowan Co. (Moore) ${ }^{a}$

17.) Wake Co. (Ball) ${ }^{b}$

${ }^{\mathrm{b}}$ Experimental site for Frankliniella fusca survey.

Fig. 1. Collection sites for thrips population surveys, Tomato spotted wilt virus surveys, and plant community assessments in North Carolina. 
Plant species abundance. To further examine the role of wild plant species as potential sources of both reproducing populations of thrips and TSWV, the abundance and distribution of species was determined monthly at each location in both seasons. The border surrounding each field and the field interior were subdivided into quadrants. The distribution and abundance of plant species was estimated by randomly throwing a 1-m square five times in each interior and border quadrant. The square meter was further subdivided into $0.25 \mathrm{~m}^{2}$ sections, and the abundance of plants was indicated by the proportion of $0.25 \mathrm{~m}^{2}$ in which a particular species was present.

TSWV infection. Seasonal TSWV infection was determined from fall 1997 through fall 2000 at 12 locations in North Carolina (Fig. 1). In each seasonal survey, the 10 most abundant plant species at each location were assayed for TSWV by double antibody sandwich enzyme-linked immunosorbent assay (DAS-ELISA) (Agdia, Inc., Elkhart, IN) with antisera to the $\mathrm{N}$ protein. For each species, up to 100 leaf samples were randomly collected at each location and partitioned into 10 groups of 10 leaf samples per group for DASELISA. Plant extract from composite sam- ples was diluted 1:10 wt/vol in general extract buffer (Agdia) and replicated twice in an alkaline-phosphatase labeled DASELISA, at an enzyme/protein ratio of 5:1 $\mathrm{vol} / \mathrm{vol}$, and held overnight at $4^{\circ} \mathrm{C}$. All assays were conducted in NUNC-Immuno flat-bottomed plates with $100 \mu \mathrm{l}$ of reagent used in each step and then scored on a THERMOmax microtiter plate reader (Molecular Devices Corp., Menlo Park, CA) at a transmission wavelength of 405 nm. A leaf sample was considered TSWVinfected if the optical density was greater than the mean plus 3 standard deviations of the noninfected controls of the same plant species. Healthy control plants were obtained from a field location in Wake County where no prior TSWV infections have been recorded. Where enough extra leaf material remained following DASELISA, grouped samples resulting in a positive DAS-ELISA reading were mechanically rub-inoculated on Carborundum-dusted leaves of 3-week-old Emilia sonchifolia (L.) DC. ex Wight according to Stobbs et al. (31) to confirm TSWV infection by symptom expression and further DAS-ELISA.

TSWV infection in perennial plants. To evaluate the role of perennial weeds as sources for both virus and thrips vectors,
TSWV-infected Plantago rugelii and $\mathrm{Ru}$ mex crispus were transplanted into field plots in October 1998 and monitored for infection over a 2-year period. Specifically, 100 seedling-stage plants of each species were mechanically rub-inoculated with a tobacco isolate of TSWV (RG2-TSWV; Carteret County, NC 1996) in a virus-free greenhouse. After 21 days, 50 systemically infected plants of each species (confirmed by DAS-ELISA) were transplanted into $6.25 \mathrm{~m}^{2}$ plots in five experimental blocks of 10 plants per block. Fifty healthy plants of each species were also transplanted into similar-sized plots at the same location. All surviving plants were counted and analyzed by DAS-ELISA in May and October of 1999 and May 2000. Mean percent infection values reported for each species were calculated based on the number of living plants remaining on each sample date. In May 2000, 10 whole TSWVinfected plants of both species were cut at the soil surface and returned to the laboratory, where adult and immature thrips were collected as described. All adult thrips, including those reared as immatures from green bean pods, were counted and identified. All thrips collected as immatures and reared to adult stage were individually subjected to a petunia leaf disk assay (37)

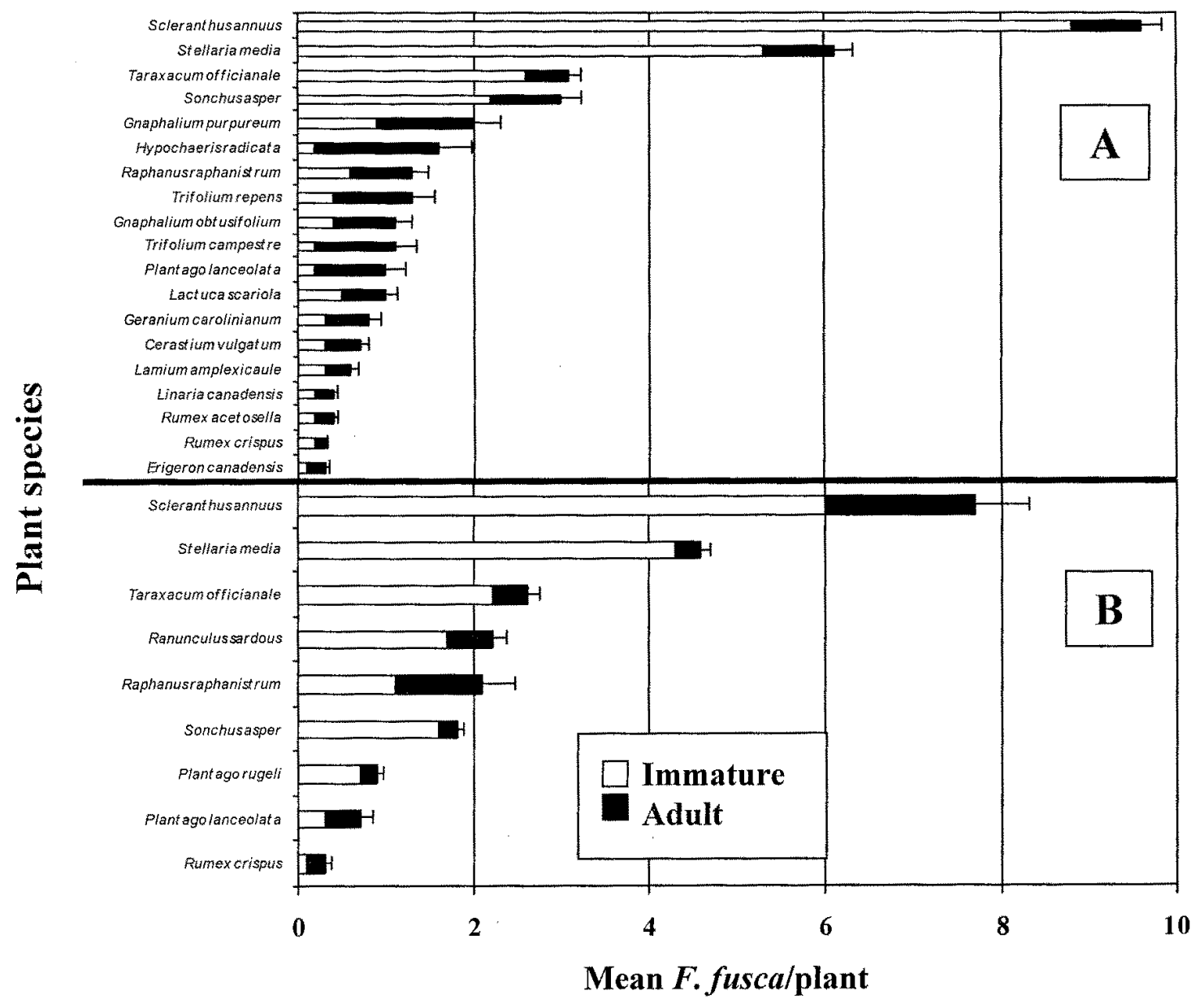

Fig. 2. Mean $( \pm$ SEM) number of total (adult + immature) Frankliniella fusca collected from weed species averaged across A, three experimental sites surveyed in 1996-97 and $\mathbf{B}$, four sites in 1998-99. 
to determine their ability to transmit TSWV. Circular leaf disks $\left(1 \mathrm{~cm}^{2}\right)$ of $P e$ tunia hybrida var. Celebrity Blue were used, and the presence of TSWV in suspected lesions was confirmed by DASELISA. Thrips used in this bioassay were later identified to species.

Relative inoculum potential (RIP) index. To more clearly identify those plant species likely of greatest importance in the transmission cycles of TSWV, we consolidated information from our surveys on suitability for reproduction by $F$. fusca and frequency of infection with TSWV into a single RIP index value for each plant species. The RIP index value for each plant species was calculated as: (percentage of sites in which a weed species occurred that contained one or more TSWV-infected plants of any species) * (estimated percentage of plants of subject species infected with TSWV) * (proportion of total immature $F$. fusca encountered in samples of all weed species in the survey that occurred on the subject species).

This index incorporates information on how commonly a weed species was infected both among and within locations and an estimate of its relative suitability as a reproductive host for $F$. fusca. It provides a basis for comparing the relative potential of various weeds included in our survey to serve as a source of inoculum for spread of TSWV in the areas and years in which we conducted our surveys.

Data analysis. Comparisons of mean thrips populations among plant species were conducted using ANOVA (PROC GLM; LSMEANS). In these experiments, thrips counts were log transformed for normalization. Percent infection data were arcsine square root transformed to normalize variance, and comparisons of means within sample locations were conducted using ANOVA. Maximum likelihood esti- mated rates of infection for a particular species were determined for each weed species where $\geq 1 \mathrm{TSWV}$-infected plant per location was detected (32). All means presented in tables and figures were backtransformed, and all statistical tests were conducted using SAS, version 7, (SAS Institute, Cary, NC).

\section{RESULTS}

Thrips populations. In the 1996-97 winter season, thrips species previously reported as vectors of TSWV comprised $77 \%(\mathrm{~N}=15,505)$ of all thrips collected $(\mathrm{N}$ $=20,136)$. Of these, $96 \%(\mathrm{~N}=14,877)$ were $F$. fusca, $2.5 \%(\mathrm{~N}=385)$ were $F$. occidentalis, and the remaining $1.5 \%(\mathrm{~N}=$ 243) were Thrips tabaci. Although fewer plant species were surveyed in 1998-99, the proportion of TSWV thrips vector species collected $(84 \% ; \mathrm{N}=4,399)$ again far exceeded that of non-TSWV vectors $(16 \%$; $\mathrm{N}=844$ ). The proportions of TSWV vectors collected in 1998-99 were nearly identical to those of the previous season: $95 \%$ $F$. fusca $(\mathrm{N}=4,189)$ with the remaining $5 \%$ split equally between $F$. occidentalis $(\mathrm{N}=105)$ and T. tabaci $(\mathrm{N}=105)$. Because $F$. fusca was the dominant TSWV vector present on the range of plant species sampled, we present only results for $F$. fusca.

Throughout the 1996-97 survey, populations of F. fusca varied substantially among the plant species equally sampled at the three locations (Fig. 2A) $(F=2.32$, df $=$ $15,75, P=0.0007)$. Among the locations sampled, Scleranthus annuus, Stellaria media, Taraxacum officianale, Sonchus asper, and Gnaphalium purpureum were the top five plant species supporting $F$. fusca reproduction. Similarly, mean proportions of immature $F$. fusca averaged over monthly samples also varied among plant species $(F=2.40$, df $=15,75, P=$ 0.0016 ), indicating that not all plant spe- cies surveyed supported equal amounts of reproduction. Immature $F$. fusca were abundant relative to adult numbers on only a few host species, including Sonchus asper, Stellaria media, and Taraxacum officianale. Averaging across these three weed species at both locations, the ratio of immature to adult $F$. fusca was $6.2: 1$, whereas the ratio averaged over the remainder of host plants was 0.29:1, suggesting that although nearly all of the weeds surveyed supported some adult thrips throughout the winter, most species supported low levels of reproduction.

In the 1998-99 survey, only nine plant species were sampled, four of which (Scleranthus annuus, Sonchus asper, Stellaria media, and Taraxacum officianale) represented species previously supporting above-average mean numbers of $F$. fusca in the 1996-97 survey season and another two species (Plantago lanceolata and $R u$ mex crispus) representing species supporting below-average $F$. fusca numbers. Differences in mean total $F$. fusca collected were again observed among plant species over the three locations surveyed $(F=$ 9.01, df $=4,8, P=0.0104$ ) (Fig. 2B). Similarly, proportions of immature $F$. fusca varied among plant species $(F=8.83, \mathrm{df}=$ $4,8, P=0.0091)$, with the largest populations again observed on Scleranthus annuus, Stellaria media, and Taraxacum officianale and a tabulated ratio of immature to adult $F$. fusca of $8.3: 1$. Mean proportions of immatures were again less on Plantago lanceolata and Rumex crispus, resulting in an estimated immature to adult ratio of $0.74: 1$.

Weed abundance. In the 1998-99 overwintering survey, populations of plant species varied in abundance both spatially and temporally among the four survey locations. Ranunculus sardous and Plantago rugelii were very abundant at the

Table 1. Occurrence (mean-percent) of Cerastium vulgatum, Plantago rugelii, Ranunculus sardous, Sonchus asper, Stellaria media, and Taraxacum officianale in the borders (B) and the interior (I) of fields located at four experimental locations during October 1998 through May 1999

\begin{tabular}{|c|c|c|c|c|c|c|c|c|c|c|c|c|c|}
\hline \multirow[b]{3}{*}{ Location } & \multirow[b]{3}{*}{ Month } & \multicolumn{12}{|c|}{ Plant species a/position } \\
\hline & & \multicolumn{2}{|c|}{ C. vulgatum } & \multicolumn{2}{|c|}{ P. rugelii } & \multicolumn{2}{|c|}{ R. sardous } & \multicolumn{2}{|c|}{ S. asper } & \multicolumn{2}{|c|}{ S. media } & \multicolumn{2}{|c|}{ T. officianale } \\
\hline & & B & $\mathbf{I}$ & B & $\mathbf{I}$ & B & $\mathbf{I}$ & B & $\mathbf{I}$ & B & $\mathbf{I}$ & B & $\mathbf{I}$ \\
\hline \multirow{4}{*}{ Fish } & Nov & 2.3 & 0.9 & 0.0 & 0.0 & 0.0 & 0.0 & 0.1 & 0.0 & 10.2 & 0.3 & 0.1 & 0.0 \\
\hline & Jan & 1.4 & 1.1 & 0.0 & 0.0 & 0.0 & 0.0 & 0.0 & 0.0 & 7.8 & 0.0 & $<0.1$ & 0.0 \\
\hline & Mar & 1.6 & 0.8 & 0.0 & 0.0 & 0.0 & 0.0 & 0.0 & 0.0 & 6.9 & $<0.1$ & $<0.1$ & 0.0 \\
\hline & Mayb & 0.1 & $<0.1$ & 0.0 & 0.0 & 0.0 & 0.0 & 0.0 & 0.0 & 8.8 & 0.0 & 0.4 & 0.0 \\
\hline \multirow[t]{4}{*}{ Honeycutt } & Nov & 1.1 & 3.1 & 0.1 & 0.0 & 0.0 & 0.0 & 1.4 & 0.0 & 21.1 & 56.7 & 2.1 & 0.0 \\
\hline & Jan & 0.7 & 2.2 & 0.0 & 0.0 & 0.0 & 0.0 & 1.1 & 0.1 & 16.4 & 69.1 & 0.7 & 0.0 \\
\hline & Mar & 0.8 & 3.8 & 0.0 & 0.0 & 0.0 & 0.0 & 1.5 & 0.1 & 29.5 & 65.4 & 1.1 & 0.0 \\
\hline & May & 0.4 & 0.1 & $<0.1$ & 0.0 & 0.0 & 0.0 & 0.3 & $<0.1$ & 18.3 & 0.1 & 0.8 & 0.0 \\
\hline \multirow[t]{4}{*}{ Jones } & Nov & 10.3 & 33.2 & 0.1 & 0.0 & 0.0 & 0.0 & 2.6 & 0.2 & 32.6 & 45.8 & 2.2 & 0.0 \\
\hline & Jan & 17.7 & 39.9 & 0.0 & 0.0 & 0.0 & 0.0 & 0.8 & 0.1 & 44.0 & 61.3 & 1.4 & 0.0 \\
\hline & Mar & 12.6 & 25.4 & 0.0 & 0.0 & $<0.1$ & 0.0 & 1.3 & 0.1 & 56.2 & 76.8 & 1.3 & 0.0 \\
\hline & Mayb & 2.0 & $<0.1$ & 0.0 & 0.1 & $<0.1$ & 0.0 & 0.1 & $<0.1$ & 38.7 & 0.3 & 1.7 & 0.0 \\
\hline \multirow[t]{4}{*}{ Williams } & Nov & 3.2 & 5.3 & 3.8 & 0.0 & 18.2 & 2.1 & 0.1 & 0.0 & 9.8 & 27.3 & 0.9 & 0.0 \\
\hline & Jan & 5.8 & 11.7 & 0.1 & 0.0 & 24.1 & 0.6 & 0.1 & 0.1 & 14.6 & 33.2 & 0.6 & 0.0 \\
\hline & Mar & 4.7 & 8.8 & 2.3 & 0.0 & 22.8 & 1.4 & 0.4 & 0.0 & 10.1 & 19.7 & 1.2 & 0.0 \\
\hline & May & 1.1 & 4.7 & 4.1 & 0.0 & 28.6 & 0.0 & $<0.1$ & 0.0 & 6.4 & 0.1 & 0.8 & 0.0 \\
\hline
\end{tabular}

a Mean percent of $0.25 \mathrm{~m}^{2}$ samples containing $\geq 1$ plant of the specified plant species.

${ }^{\mathrm{b}}$ Indicates in-field tillage prior to this sample date. 
Granville County site (Williams) but were relatively rare or even absent at the remaining locations (Table 1). Populations of Taraxacum officianale were less variable among survey sites but were noticeably more prevalent in the field borders, where plants remained undisturbed for longer periods than in field interiors, which received annual tillage. Furthermore, populations of Taraxacum officianale remained relatively unchanged throughout the survey period, unlike populations of Cerastium vulgatum, Sonchus asper, and Stellaria media, which markedly declined by the final sample date as a result of increased daytime temperatures in mid to late spring and land preparation practices (tillage) at some locations.

TSWV prevalence. In surveys from 1997 through 2000, TSWV infection was detected at 11 of 12 sites $(91.7 \%)$ and in 35 of 72 plant species (49\%) across 18 plant families (Table 2). Nine plant species collected were determined to be new host recordings, which included Aizoaceae: Mollugo verticillata L. (carpetweed);
Campanulaceae: Triodanis perfoliata (L.) A. DC. (Venus's looking glass); Compositae: Eupatorium capillifolium (Lam.) Small (dog fennel), Gnaphalium purpureum, Pyrrhopappus carolinianus (Walt.) DC. (Carolina false-dandelion); Raphanus raphanistrum, Cardamine hirsuta; Geranium carolinianum; and Linaria canadense (Table 2). Of the total infected plants, $43 \%(\mathrm{~N}=15)$ were confirmed TSWV-infected through mechanical inoculations to E. sonchifolia, whereas $6 \%(\mathrm{~N}=$ 2) failed to produce a systemic infection in

Table 2. Survey of annual (A), biennial (B), and perennial (P) plant species for Tomato spotted wilt virus (TSWV) infection and Frankliniella fusca infestation at 13 locations in eastern North Carolina from 1997 through 2000

\begin{tabular}{|c|c|c|c|c|c|}
\hline $\begin{array}{l}\text { Plant family } \\
\text { Species }\end{array}$ & Plant type & $\begin{array}{l}\text { Sites } \geq 1 \text { TSWV infection/ } \\
\text { total sites surveyed }\end{array}$ & $\begin{array}{l}\text { Composite samples positive } \\
\text { for TSWV/total samples }^{\mathrm{a}}\end{array}$ & $\begin{array}{l}\text { Mean } F \text {. fusca } \\
\text { per plant }\end{array}$ & RIP index ${ }^{b}$ \\
\hline \multicolumn{6}{|l|}{ Aizoaceae } \\
\hline Mollugo verticillata ${ }^{\mathrm{c}}$ & A & $7 / 12$ & $52 / 147(4.3)^{\mathrm{d}}$ & $\ldots$ & $\ldots$ \\
\hline \multicolumn{6}{|l|}{ Amaranthaceae } \\
\hline Amaranthus retroflexus & A & $1 / 12$ & $12 / 198(0.6)^{\mathrm{d}}$ & 0.1 & $\ldots$ \\
\hline \multicolumn{6}{|l|}{ Campanulaceae } \\
\hline Specularia perfoliata $^{\mathrm{c}}$ & A & $1 / 5$ & $1 / 34(0.3)$ & $\ldots$ & $\ldots$ \\
\hline \multicolumn{6}{|l|}{ Caryophyllaceae } \\
\hline Cerastium vulgatum & $\mathrm{P}$ & $5 / 10$ & $250 / 717(4.2)^{\mathrm{d}}$ & 1.7 & 8.4 \\
\hline Stellaria media & A & $7 / 12$ & $26 / 199(1.4)$ & 2.3 & 5.1 \\
\hline \multicolumn{6}{|l|}{ Chenopodiaceae } \\
\hline Chenopodium album & A & $1 / 9$ & $1 / 38(0.3)$ & $\ldots$ & $\ldots$ \\
\hline \multicolumn{6}{|l|}{ Compositae } \\
\hline Ambrosia artemisifolia & A & $5 / 12$ & $15 / 148(1.1)^{\mathrm{d}}$ & 0.1 & . \\
\hline Erigeron canadense & A & $3 / 12$ & $4 / 184(0.2)$ & 0.5 & 0.1 \\
\hline Eupatorium capillifolium ${ }^{\mathrm{c}}$ & $\mathrm{A} / \mathrm{P}$ & $1 / 11$ & $2 / 164(0.1)$ & $\ldots$ & $\ldots$ \\
\hline Gnaphalium purpureum ${ }^{\mathrm{c}}$ & A & $5 / 12$ & $13 / 154(0.8)$ & 2.1 & 1.7 \\
\hline Lactuca scariola & A & $6 / 11$ & $22 / 178(1.3)^{\mathrm{d}}$ & 1.3 & 2.1 \\
\hline Pyrrhopappus carolinianus ${ }^{\mathrm{c}}$ & B & $3 / 8$ & $5 / 141(0.3)$ & $\ldots$ & $\ldots$ \\
\hline Solidago spp. & $\mathrm{P}$ & $2 / 12$ & $2 / 172(0.1)$ & $\ldots$ & $\ldots$ \\
\hline Sonchus asper & A & $9 / 12$ & $60 / 145(5.2)^{\mathrm{d}}$ & 1.4 & 11.7 \\
\hline Taraxacum officianale & $\mathrm{P}$ & $5 / 10$ & $97 / 216(5.8)^{\mathrm{d}}$ & 2.1 & 14.5 \\
\hline Xanthium strumarium & A & $2 / 8$ & $3 / 146(0.2)$ & $\ldots$ & $\ldots$ \\
\hline \multicolumn{6}{|l|}{ Convolvulaceae } \\
\hline Ipomoea hederacea & A & $4 / 10$ & $5 / 140(0.4)^{\mathrm{d}}$ & $\ldots$ & $\ldots$ \\
\hline \multicolumn{6}{|l|}{ Cruciferae } \\
\hline Cardamine hirsuta ${ }^{\mathrm{c}}$ & A & $3 / 10$ & $14 / 148(1.0)^{\mathrm{d}}$ & $<0.1$ & 0.2 \\
\hline Coronopus didymus & A & $1 / 3$ & $3 / 94(0.3)^{\mathrm{d}}$ & $\ldots$ & $\ldots$ \\
\hline Raphanus raphanistrum ${ }^{c}$ & A & $1 / 5$ & $2 / 92(0.2)$ & 1.5 & 0.2 \\
\hline \multicolumn{6}{|l|}{ Fabaceae } \\
\hline Cassia obtusifolia & A & $2 / 8$ & $4 / 125(0.3)$ & $\ldots$ & $\ldots$ \\
\hline Crotalaria spectabilis & A & $1 / 1$ & $1 / 2(6.7)$ & $\ldots$ & $\ldots$ \\
\hline Trifolium repens & $\mathrm{P}$ & $1 / 8$ & $5 / 160(0.3)$ & 0.4 & 0.1 \\
\hline \multicolumn{6}{|l|}{ Geraniaceae } \\
\hline Geranium carolinianum $^{\mathrm{c}}$ & A & $4 / 12$ & $22 / 207(1.1)$ & 0.8 & 0.7 \\
\hline \multicolumn{6}{|l|}{ Labiatae } \\
\hline Lamium amplexicaule & A & $2 / 11$ & $4 / 148(0.3)$ & 1.0 & 0.1 \\
\hline \multicolumn{6}{|l|}{ Onagraceae } \\
\hline Oenothera laciniata & B & $1 / 12$ & $1 / 159(0.1)$ & 1.6 & 0.1 \\
\hline \multicolumn{6}{|l|}{ Oxalidaceae } \\
\hline Oxalis acetosella & $\mathrm{P}$ & $1 / 10$ & $3 / 169(0.2)$ & $\ldots$ & $\ldots$ \\
\hline \multicolumn{6}{|l|}{ Plantaginaceae } \\
\hline Plantago lanceolata & $\mathrm{P}$ & $3 / 7$ & $3 / 205(0.1)$ & 0.9 & 0.1 \\
\hline Plantago rugelii & $\mathrm{P}$ & $6 / 11$ & $73 / 268(3.1)$ & 1.9 & 8.5 \\
\hline \multicolumn{6}{|l|}{ Polygonaceae } \\
\hline Polygonum pensylvanicum & A & $7 / 12$ & $15 / 160(1.0)^{\mathrm{d}}$ & 0.4 & \\
\hline Rumex crispus & $\mathrm{B} / \mathrm{P}$ & $5 / 12$ & $24 / 264(0.9)^{\mathrm{d}}$ & 0.2 & 0.4 \\
\hline \multicolumn{6}{|l|}{ Ranunculaceae } \\
\hline Ranunculus bulbous & $\mathrm{P}$ & $2 / 4$ & $9 / 263(0.4)$ & 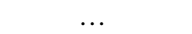 & $\ldots$ \\
\hline Ranunculus sardous & A & $6 / 11$ & $58 / 178(3.9)^{\mathrm{d}}$ & 2.1 & 10.7 \\
\hline \multicolumn{6}{|l|}{ Scrophulariaceae } \\
\hline Linaria canadense $^{\mathrm{c}}$ & $\mathrm{A} / \mathrm{B}$ & $1 / 3$ & $7 / 90(0.8)$ & 0.4 & 0.3 \\
\hline \multicolumn{6}{|l|}{ Solanaceae } \\
\hline Solanum carolinense & $\mathrm{P}$ & $1 / 6$ & $1 / 62(0.2)$ & $\ldots$ & $\ldots$ \\
\hline
\end{tabular}

a Maximum likelihood estimated percent TSWV infection within an individual plant species (31).

${ }^{\mathrm{b}}$ Relative inoculum potential index.

${ }^{c}$ New host recording.

${ }^{\mathrm{d}}$ Indicates positive bioassay for TSWV through mechanical inoculation to Emilia sonchifolia. 
E. sonchifolia through mechanical inoculations, and the remaining $51 \%(\mathrm{~N}=18)$ were not tested using mechanical inoculations. Maximum likelihood estimated rates of TSWV infection within individual species were generally very low $(\leq 1.0 \%)$, when averaged over all survey locations, with the exception of the Molluga verticillata $(4.3 \%)$, Cerastium vulgatum (4.2\%), Stellaria media (1.4\%), Lactuca scariola (1.3\%), Sonchus asper (5.1\%), Taraxacum officianale (5.8\%), Plantago rugelii (3.4\%), and Ranunculus sardous $(3.6 \%)$. These species were infected at $\geq 50 \%$ of the 10 or more locations in which they were sampled. No TSWV infection was detected in Amaranthaceae: Amaranthus spinosus L. (spiny amaranth); Bignoniaceae: Campsis radicans (L.) Seem. (trumpet creeper); Boraginaceae: Lappula echinata Gilib. (beggar's lice); Caprifoliaceae: Lonicera japonica Thunb. (honeysuckle); Chenopodiaceae: Chenopodium ambrosioides L. (Mexican tea); Compositae: Achillea millefolium L. (yarrow), Anthemis cotula L. (mayweed), Aster novae-angliae L. (New England aster), Galinsoga ciliata (Raf.) Blake (Peruvian daisy), Gnaphalium obtusifolium L. (sweet everlasting), Helenium amarum (Raf.) H. Rock (bitter sneezeweed), Hypochaeris radicata $\mathrm{L}$. (cat's-ear); Cruciferae: Capsella bursapastoris (L.) Medik. (shepherd's purse), Lepidium virginicum L. (peppergrass), Rorippa islandica (Oeder) Borbas. (marsh yellow cress); Fabaceae: Lespedeza cuneata (Dumont) G. Don (common lespedeza), Trifolium arvense L. (rabbit clover), Vicia villosa Roth (hairy vetch); Hamamelidaceae: Liquidambar styraciflua L. (sweet-gum); Liliaceae: Smilax glauca Walter (greenbrier); Malvaceae: Malva sylvestris L. (high mallow); Onagraceae: Oenothera biennis L. (common evening primrose); Phytolaccaceae: Phytolacca americana L. (pokeweed); Plantaginaceae: Plantago aristata Michx. (bracted plantain); Polygonaceae: Rumex acetosella L. (red sorrel), Rumex obtusifolius L. (sour dock); Portulacaceae: Portulaca oleracea L. (purslane); Ranunculaceae: Ranunculus parviflorus L. (smallflower crowfoot); Rosaceae: Rosa carolina L. (wild rose), Rubus laciniatus Willd. (blackberry); Rubiaceae: Diodia teres Walt. (poor-Joe), Richardia scabra L. (Florida pusley); Solanaceae: Physalis heterophylla Nees (ground cherry); Umbelliferae: Daucus carota L. (wild carrot); Urticaceae: Parietaria pensylvanica Muhl. ex Willd. (pellitory); and Rianaceae: Valerianella radiata (L.) Dufr. (corn salad).

Infected plant species included perennial $(\mathrm{N}=10)$, biennial $(\mathrm{N}=4)$, and annual $(\mathrm{N}=$ 21) plant species. Averaged over the 1997 , 1998, and 1999 fall season surveys, TSWV infection was detected most frequently in grouped samples of the perennials Plan- tago rugelii (averaging 4.7 infected, grouped samples per season) and Rumex crispus (1.8 sample per season), followed by the annual species Polygonum pensylvanicum (2 samples per season), Sonchus asper (1.8 samples per season), and Ambrosia artemisifolia L. (common ragweed) (1.5 samples per season) (Fig. 3A). The remainder of plant species in which TSWV infection was serologically detected in fall seasons averaged $\leq 1$ grouped sample per season. Furthermore, many newly germinated winter annual species were found to be infected with TSWV at this time, including Cardamine hirsuta, Geranium carolinianum, Lamium amplexicaule; Oxalidaceae: Oxalis acetosella L. (wood sorrel), and Stellaria media, although mean infection levels were low. Overall, the smallest numbers of TSWV infections were recorded in these fall surveys, averaging $<1$ infected group sample per season across all 16 weed species surveyed.

Averaging over the two winter surveys (1997-98 and 1998-99), plant species most often TSWV-infected included the perennial species Cerastium vulgatum (averaging 31 samples per season) and Taraxacum officianale (20.5 samples per season) and annual species Sonchus asper (13 samples per season) and Stellaria media (12.2 samples per season), while the remainder of species tested averaged $\leq 7 \mathrm{TSWV}$-infected group samples per season (Fig. 3B). The winter surveys produced the greatest mean number of infected group samples per season, averaging just over seven infected samples per season for the 15 different plant species surveyed.

The species most commonly infected by TSWV (averaging over both spring seasons) again included the perennials Plantago rugelii (averaging 18 samples per season) and Taraxacum officianale (16.8 samples per season), and the annual species Sonchus asper (12 samples per season), Stellaria media, and Ranunculus sardous (both averaging 10 TSWVinfected grouped samples per season) (Fig. $3 C)$. Here again, the remainder of species tested in both spring seasons averaged $\leq 7$ TSWV-infected grouped samples per season. Notably, many newly germinated summer annual species were detected with TSWV infections in these early spring surveys, including Molluga verticillata; Chenopodiaceae: Chenopodium album L. (lamb's quarters); Compositae: Ambrosia artemisifolia, Erigeron canadense L. (horseweed); Convolvulaceae: Ipomoea hederacea (L.) Jacq. (blue morning-glory); Cruciferae: Coronopus didymus L. (Smith) (swinecress); and Fabaceae: Cassia obtusifolia L. (sicklepod). On average, spring surveys produced 5 TSWV-infected grouped samples per season averaged over 21 weed species.

Across each of the three summer surveys, the most commonly infected perenni- als included Taraxacum officianale (averaging 8.5 samples per season), Plantago rugelii (7 samples per season), and Rumex crispus (5.3 samples per season) (Fig. 3D). TSWV-infected annuals Molluga verticillata, Ranunculus sardous, Ambrosia artemisifolia, and Polygonum pensylvanicum were also frequently infected, averaging 16.8, 5, 2, and 2 TSWV-infected grouped samples per season, respectively. Summer TSWV surveys yielded, on average, just under three TSWV-infected group samples per season across the 22 weed species surveyed.

TSWV infection in perennial plants. The role of perennial plants as potential sources for TSWV and their associated vectors was further investigated in smallplot field tests involving TSWV-infected Plantago rugelii and Rumex crispus over a 2-year period. Mean TSWV infection levels did not differ between the two perennial species over the course of the experiment $(F=0.68$, df $=1,14, P=0.4243)$. Throughout this experiment, the incidence of TSWV infection in both species remained high $(100.0 \%)$ over the course of the first winter season but declined to 80 and 70\% infected plants in October 1999 for Plantago rugelii and Rumex crispus, respectively. On the final sample date in May 2000, infection continued to decline, averaging 42 and $40 \%$ for Plantago rugelii and Rumex crispus, respectively. Overall plant mortality did not differ between TSWV-infected and healthy Plantago rugelii $(F=0.04$, df $=1,14, P=0.8734)$ and Rumex crispus $(F=0.02$, df $=1,14, P$ $=0.9131$ ), averaging $\leq 8.0 \%$ across both species and infection status. TSWV infection was not detected in uninoculated control plants.

Populations of TSWV vectors infesting both TSWV-infected and healthy Plantago rugelii and Rumex crispus were examined on the final sample date of the experiment (May 2000). F. fusca comprised the majority of immature TSWV vectors recovered from Plantago rugelii $(98.4 \%)$ and Rumex crispus $(99.6 \%)$ and averaged 1.7 and 1.1 immature $F$. fusca per plant, respectively. TSWV infection of the host plant did not significantly influence the mean abundance of total $F$. fusca $(F=1.20, \mathrm{df}=1,18, P=$ $0.2884)$, or of either adults $(F=1.58, \mathrm{df}=$ $1,18, P=0.2249)$, or immatures $(F=0.42$, df $=1,18, P=0.5258)$, averaged over plant species.

\section{DISCUSSION}

Because individual thrips can transmit TSWV only if they have acquired the virus as an immature, only plant species that serve as hosts for the virus and as reproductive hosts for thrips vector species can be considered important in virus spread $(1,30,35)$. Hence, plant species that are susceptible to TSWV infection but are poor hosts for reproduction by thrips vector species are less likely to be important epi- 
demiologically than are TSWV-infected plants that support high levels of reproduction by vector species.

Results from our thrips population surveys over 2 years clearly demonstrate that a wide range of annual, biennial, and per- ennial plants are overwintering hosts for TSWV-vector species, but not all are equal in their ability to support reproducing populations of $F$. fusca. In both the 199697 and 1998-99 surveys, the annual species Scleranthus annuus, Sonchus asper, and Stellaria media, and the perennial Taraxacum officianale most consistently supported the greatest populations of immature $F$. fusca across the six survey sites. Similarly, Chamberlin et al. (4) and Cho et al. (9) reported above-average populations

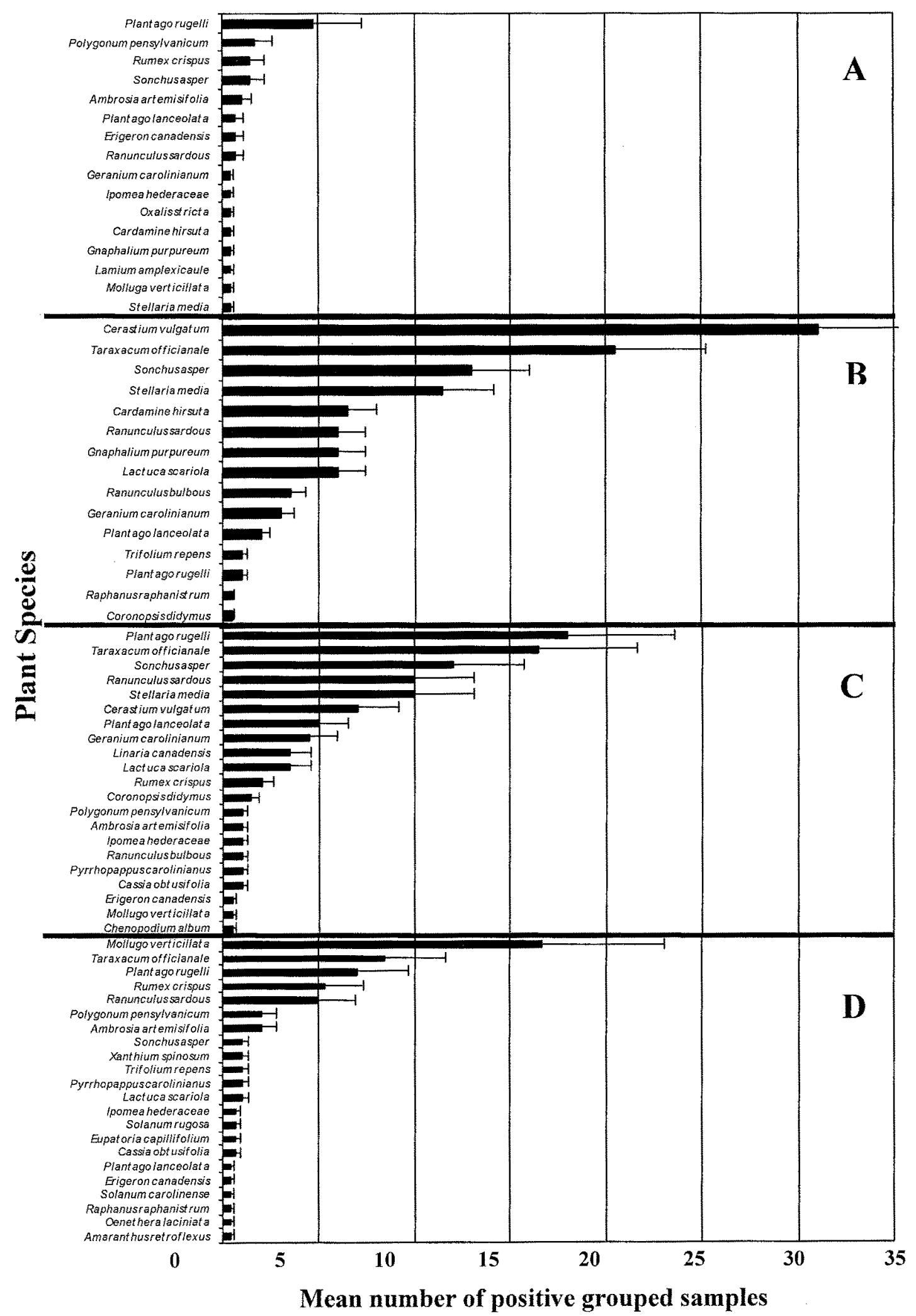

Fig. 3. Mean $( \pm$ SEM) number of composite samples testing positive for Tomato spotted wilt virus infection from plant surveys conducted in A, fall, B, winter, C, spring, and D, summer across 14 experimental sites, 1997 through 2000. 
of adult $F$. fusca present on Taraxacum officianale along with numerous immature stages; however, fewer adult stages were detected on Sonchus asper and Stellaria media, and numbers of immature thrips were below average over the range of species surveyed. In many previous thrips surveys of wild plant species $(4,5,9,18,33)$, immature thrips recovered were reported only in number, and species composition was not determined. As a result, the reproductive potentials of plant species included in these numerous surveys are difficult to interpret and directly compare with our findings.

Additional plant species that supported above-average populations of immature $F$. fusca included Gnaphalium purpureum, Hypochaeris radicata, Lactuca scariola, Lamium amplexicaule, Raphanus raphanistrum, and Trifolium campestre; however, populations of immature $F$. fusca on these species varied greatly among locations and seasons. Both Plantago rugelii and Ranunculus sardous, which were monitored for only one season at one site (Williams, Granville County), supported above-average populations of immature $F$. fusca. Similarly, Johnson et al. (17) reported finding substantial populations of $F$. fusca developing on Ranunculus sardous by rearing all immatures collected to the adult stage, whereas low numbers were recovered from Sonchus asper. Individually, the remainder of plant species surveyed supported low populations of immature $F$. fusca. Collectively, however, this group of plants could certainly contribute to the production of substantial numbers of $F$. fusca. Results from these surveys document that $F$. fusca reproduces on numerous plant species throughout the noncrop season. More importantly, they emphasize that plants that are hosts for both TSWV and $F$. fusca differ greatly in their potential to generate viruliferous thrips $(3,12,14,17$, 22,31).

Any assessment of the potential epidemiological importance of a particular plant species must also include some measure of the relative incidence of TSWV infection in that species. Surveys of potential TSWV inoculum sources in the southeastern United States have concentrated primarily on winter annual and perennial hosts that occur between cropping cycles $(3,4,9,14$, $17,18,33)$. In each case, only a limited number of plant species were considered significant contributors to the spread of TSWV to susceptible crops, based on estimates of vector populations, incidences of infection, and abundance of plants. Our random TSWV surveys revealed a substantial number of plant species infected with TSWV, nine of which were determined to be new host recordings $(7,8,14,17,20-$ $22,24,28,31)$. Although a substantial number of plant species were infected, not all of these species should be considered equally important as contributors in disease cycles. Of the 35 plant species infected with TSWV, over $34 \%(\mathrm{~N}=12)$ were found at only one, but not necessarily the same location, and an additional $26 \%(\mathrm{~N}=$ 9) were detected at only two locations (Table 2). Moreover, the maximum likelihood estimated probability that an individual plant of each species in our samples was infected with TSWV was $\leq 1 \%$ infection in 24 of the $35(69 \%)$ plant species in which infections were detected. Of the remaining plant species, those found at $>2$ sample locations and where estimated infection rates exceeded $1 \%(\mathrm{~N}=10)$ included the summer annual species Ambrosia artemisifolia and Molluga verticillata, the winter annual species Cerastium vulgatum, Geranium carolinianum, Lactuca scariola, Ranunculus sardous, Sonchus asper, and Stellaria media, and the perennials Plantago rugelii and Taraxacum officianale. In each case, infected plants occurred at over $50 \%$ of the locations surveyed, and estimated probabilities of infection ranged from 1.1 to $5.8 \%$.

The incidence of infection within a population of plants may be affected by its distribution and abundance relative to other species. In our surveys, many perennial and some biennial plant species were not uniformly distributed among survey locations and were often encountered infrequently. However, the least common species, including Plantago rugelii, Ranunculus sardous, and Taraxacum officianale from our surveys in 1998-99 (Table 1), supported above-average populations of F. fusca and may be important contributors to the enhancement of local inoculum levels. At locations where Ranunculus sardous was noticeably abundant in our TSWV surveys (Fig. 1, survey locations 5 and 6), the estimated probabilities of infection were 2.6 and $7.7 \%$, respectively. Similarly, estimated probability of infection in Plantago rugelii (5.5 and $3.1 \%$ ) was highest at field locations 3 and 6 , respectively (Fig. 1), where this species was noticeably abundant. Frequently encountered and widely distributed weed species, such as Cerastium vulgatum and S. media, are also likely to be more important on an areawide basis as overwintering hosts for TSWV and sources of TSWV spread to susceptible crops and summer annual weed hosts. Latham and Jones (22) reported substantial rates of TSWV infection in both Sonchus asper and Stellaria media, and both species were reported as widely distributed among the locations sampled.

The potential role of summer annual weeds as sources of TSWV has been largely ignored. We documented TSWV infection in nine species of summer annual weeds that commonly grow in and adjacent to fields of TSWV-infected crops (Table 2). Although the significance of these findings is not yet clear, we believe that some summer annual plant species may provide a bridge between overwintering weed hosts of TSWV and crops, and may also provide a means by which TSWV can persist through the summer season and during periods between crop harvest and the emergence of winter annual weed hosts. Johnson et al. (18) reported very sporadic and infrequent TSWV infection in summer annual weeds. The patterns of thrips dispersal and plant emergence and maturation that we have observed in the spring suggest that there is an opportunity for some of these summer annual species to become infected with TSWV and to support one or more generations of thrips prior to the end of the planting season. Results from our surveys indicate that many TSWV-infected winter annual species (Cerastium vulgatum, Ranunculus sardous, Sonchus asper, and Stellaria media) were maturing concomitantly with the emergence of many summer annual species, which were infected with TSWV (Ambrosia artemisifolia, Molluga verticillata, and Polygonum pensylvanicum). These summer annual weeds appear to become infected early in their development and harbor TSWV inoculum throughout the summer. Finally, infected plants of many of the same species were again encountered in our fall surveys, at a time when many winter annual species are germinating and very susceptible to infection. Reproducing populations of both $F$. fusca and F. occidentalis were collected from these late-season summer hosts through 15 November 2000 (G. G. Kennedy, unpublished data) and may act to move TSWV into overwintering hosts. These implied patterns of movement allow for the completion of the cycle from an over-summering annual host, concurrently supporting vector populations, to a coolseason or winter annual host which will retain the infection until the following spring.

Similarly, the epidemiological importance of TSWV-infected perennial hosts has not been fully investigated. Numerous surveys for natural TSWV infection have documented the presence of infections in perennial plant species $(3,7,14,22,28)$, but few have systematically documented the presence of reproducing thrips populations. Results from our surveys indicated that a number of perennial plant species are frequently infected with TSWV and additionally can support reproduction of $F$. fusca (Table 2). More importantly, we demonstrated that a significant proportion of infected Plantago rugelii and Rumex crispus maintained TSWV infections over a 2-year period. Consequently, TSWV-infected perennial plants may serve as a relatively persistent source of inoculum for spread to and subsequent increase in annual plants and further spread to susceptible crops. Infected perennial hosts may serve to maintain TSWV inoculum at a site during periods when spread from winter annuals to summer annuals or summer annuals to winter annuals is minimal due to condi- 
tions unfavorable for thrips population growth and dispersal or effective control of annual plants.

Clearly, understanding the relative importance of different potential transmission cycles is critical to optimizing any management strategy aimed at reducing the abundance of TSWV inoculum and spread into and potentially from crops. To more clearly identify those plant species likely of greatest importance in the transmission cycles of TSWV, we consolidated information from our surveys on suitability for reproduction by $F$. fusca and frequency of infection with TSWV into a single RIP index value for each plant species. It provides a basis for comparing the relative potentials of various weeds included in our survey to serve as sources of inoculum for spread of TSWV in the areas and years in which we conducted our surveys. Because of missing data, index values were generated for 25 species, seven of which had a computed index value of zero. The RIP values for the remaining 18 common perennial, biennial, and annual plant species ranged from 0.1 to 14.5 (Table 2). Species with the highest values were those in which multiple infected plants were common at multiple locations, and were highly suitable as reproductive hosts for $F$. fusca. There were six such species, which had index values ranging from 5.1 to 14.5: Cerastium vulgatum, Plantago rugelii, Ranunculus sardous, Sonchus asper, Stellaria media, and Taraxacum officianale. A second group of two species had intermediate RIP values of 1.7 (Gnaphalium purpureum) and 2.1 (Lactuca scariola). The remaining species had RIP values that ranged from 0.1 to 0.4 . Locally abundant populations of species in the first group are likely to represent a significant risk factor in nearby susceptible crops in areas where TSWV has occurred in the recent past. In other areas, however, where $F$. fusca is not viewed as the primary vector of TSWV, other groupings of plant species may be important contributors to disease cycles. In Australia, Latham and Jones (22) implicated only a narrow range of wild plant species, including Sonchus asper and Arctotheca calendula L. Levyns (capeweed), as important contributors to disease cycles of TSWV and assigned greater importance to adjacent infected crop plants. In this instance, the primary vector of TSWV was determined to be $F$. occidentalis, which was frequently found infesting a range of flowering ornamental and vegetable crop plants growing near or adjacent to susceptible crops impacted by TSWV infection.

Vegetation management to reduce TSWV inoculum requires knowledge of the inoculum source within an area and of the dispersal of viruliferous thrips from that source. Ullman et al. (35) described a method for locating discrete TSWV inoculum sources in irrigated production areas of California, which could then be de- stroyed. The repeated occurrence of TSWV in specific fields in North Carolina indicates the existence of local inoculum sources. At a number of such locations, we documented a high incidence of TSWVinfected plants growing around field margins, along drainage ditches, and in adjacent uncultivated land. However, we lack information on the spatial dimensions of these inoculum sources. If these sources are distributed across large areas involving many plant species, then TSWV source reduction through vegetation management will be more costly and complex than if they occur in one or a few plant species growing in discrete patches of infection.

Knowledge of the relationship between distance from the virus source and virus incidence in a susceptible crop is important to the success of any effort to reduce virus incidence through source reduction. Spread of TSWV from a localized source by $F$. occidentalis in Australia reportedly involved gradients of infection spread over $12 \mathrm{~m}$ (22). Information on gradients of TSWV spread by $F$. fusca in the southeastern United States is lacking, although Groves et al. (15) failed to detect gradients of infection in weed hosts over a distance of ca. $35 \mathrm{~m}$ from a localized TSWV source. Detailed information on gradients of spread from virus sources is needed to identify situations in which source reduction is feasible and to develop guidelines for effective TSWV source reduction.

Sustainable management of TSWV will require multiple tactics (6). Controlling alternate hosts of viruses and vectors has been an important component of TSWV management in Hawaii $(1,6)$. Because vector control using insecticides is of limited effectiveness in reducing spread of TSWV into susceptible crops $(13,34)$ and commercially acceptable TSWV-resistant varieties are not yet available, successful long-term management of TSWV may require the ability to reduce or eliminate local sources of inoculum. Consequently, considerable effort has been devoted to identifying potential overwintering sources of TSWV and to defining potential reproductive hosts of vectors in the southeastern United States $(4,5,9,17,25)$. Our findings expand on previous work by documenting the relative potential of a number of common annual, biennial, and perennial weed species to contribute to the maintenance and spread of TSWV in the southeastern United States where these species commonly occur and F. fusca appears to be the primary vector.

\section{ACKNOWLEDGMENTS}

We thank Carol Berger, Rebecca Bryan, Kate Coward, Bryan Bumgarner, and Vann Covington for technical assistance with field surveys. This work was supported, in part, by the North Carolina Agriculture Research Service, and grants from the USDA Southern Region IPM Program (grant no. 96-34103-3336) and the North Carolina Tobacco Commission.
LITERATURE CITED

1. Bautista, R., Mau, R. F. L., Cho, J. J., and Custer, D. 1996. Thrips, tospoviruses, and host-plant associations in a Hawaiian farm ecosystem: Prospects for reducing disease losses. Acta Hortic. 431:477-482.

2. Best, R. J. 1968. Tomato spotted wilt virus. Adv. Vir. Res. 13:65-145.

3. Bond, W. P., Whitam, H. K., and Black, L. L. 1983. Indigenous weeds as reservoirs of tomato spotted wilt virus in Louisiana. (Abstr.) Phytopathology 73:499.

4. Chamberlin, J. R., Todd, J. W., Beshear, R. J., Culbreath, A. K., and Demski, J. W. 1992. Overwintering hosts and wingform of thrips, Frankliniella spp., in Georgia (Thysanoptera: Thripidae): Implications for management of spotted wilt disease. Environ. Entomol. 21:121-128.

5. Chellemi, D. O., Funderburk, J. E., and Hall, D. W. 1994. Seasonal abundance of flowerinhabiting Frankliniella species (Thysanoptera: Thripidae) on wild plant species. Environ. Entomol. 23:337-342.

6. Cho, J. J., Mau, R. F. L., German, T. L. Hartmann, R. W., Yudin, L. S., Gonsalves, D. and Provvidenti, R. 1989. A multidisciplinary approach to management of tomato spotted wilt virus in Hawaii. Plant Dis. 73:375-383.

7. Cho, J. J., Mau, R. F. L., Gonsalves, D., and Mitchell, W. C. 1986. Reservoir weed hosts of tomato spotted wilt virus. Plant Dis. 70:10141017.

8. Cho, J. J., Mau, R. F. L., Mitchell, W. C., Gonsalves, D., and Yudin, L. S. 1987. Host list of plants susceptible to tomato spotted wilt virus (TSWV). Univ. Hawaii Coll. Trop. Agric. Hum. Resour. Res. Ext. Ser. 078.

9. Cho, K., Eckel, C. S., Walgenbach, J. F., and Kennedy, G. G. 1995. Overwintering of thrips (Thysanoptera: Thripidae) in North Carolina. Environ. Entomol. 24:58-67.

10. Culbreath, A. K., Csinos, A. S., Bertrand, P. F., and Demski, J. W. 1991. Tomato spotted wilt virus epidemic in flue-cured tobacco in Georgia. Plant Dis. 75:483-485.

11. Duffus, J. E. 1971. Role of weeds in the incidence of virus diseases. Annu. Rev. Phytopathol. 9:319-340.

12. Eckel, C. S., Cho, K., Walgenbach, J. F., Kennedy, G. G., and Moyer, J. W. 1996 Variation in thrips species composition in field crops and implications for tomato spotted wilt epidemiology in North Carolina. Entomol. Exp. Appl. 78:19-29.

13. Funderburk, J., Olson, S., and Puche, H. 1990. Insecticidal control of thrips in tomatoes with implications for management of tomato spotted wilt virus. Pages 31-40 in: Proc. Florida Tomato Inst. W. M. Stall, ed.

14. Gitaitis, R. D., Dowler, C. C., and Chalfant, R. B. 1998. Epidemiology of tomato spotted wilt in pepper and tomato in southern Georgia. Plant Dis. 82:752-756.

15. Groves, R. L., Walgenbach, J. F., Moyer, J. W., and Kennedy, G. G. 2001. Overwintering of Frankliniella fusca Hinds (Thysanoptera: Thripidae) on winter annual weeds infected with Tomato spotted wilt virus and patterns of virus movement between susceptible weed hosts. Phytopathology 91:891-899.

16. Hagan, A. K., Weeks, J. R., French, J. C. Gudauskas, R. T., Mullen, J. M., Gazaway, W. S., and Shelby, R. 1990. Tomato spotted wilt virus in peanut in Alabama. Plant Dis. 74:615.

17. Johnson, R. R., Black, L. L., Hobbs, H. A Valverde, R. A., Story, R. N., and Bond, W. P. 1995. Association of Frankliniella fusca and three winter weeds with tomato spotted wilt virus in Louisiana. Plant Dis. 79:572576.

18. Johnson, W. C. I., Todd, J. W., Culbreath, A K., and Mullinix, J. B. G. 1996. Role of 
warm-season weeds in spotted wilt epidemiology in the southeastern coastal plain. Agron. J. 88:928-933.

19. Jones, R. K., and Baker, J. R. 1991. TSWV: Symptoms, host range and spread. VirusThrips-Plant Interaction of Tomato Spotted Wilt Virus. H. Hsu and R. H. Lawson, eds. Proc. USDA Workshop, USDA-ARS Bull. ARS-87.

20. Jorda, C., Ortega, A., and Juarez, M. 1995. New hosts of tomato spotted wilt virus. Plant Dis. 79:538.

21. Kaminska, M., and Korbin, M. 1994. New natural hosts of tomato spotted wilt virus. Acta Hortic. 377:123-128.

22. Latham, L. J., and Jones, R. A. C. 1997. Occurrence of tomato spotted wilt tospovirus in native flora, weeds, and horticultural crops. Aust. J. Agric. Res. 48:359-369.

23. McPherson, R. M., Pappu, H. R., and Jones, D. C. 1999. Occurrence of five thrips species on flue-cured tobacco and impact on spotted wilt disease incidence in Georgia. Plant Dis. 83:765-767

24. Mertilik, J., Mokra, V., Gotzova, B., and Pechova, D. 1998. Natural occurrence of tomato spotted wilt virus in several weed plant species in the Czech Republic. Page 96 in: Recent Progress in Tospovirus and Thrips Research. D. Peters and R. Goldbach, eds. Wageningen, Netherlands.
25. Mitchell, F. L., and Smith, J. W. 1991. Epidemiology of tomato spotted wilt virus relative to thrips populations. Pages 46-52 in: Virus-Thrips-Plant Interactions of Tomato Spotted Wilt Virus. Proc. USDA Workshop. USDA-ARS Bull. ARS-87.

26. Mound, L. A. 1996. The Thysanoptera vector species of Tospoviruses. Acta Hortic. 431:298-309.

27. Palmer, J. M., Mound, L. A., and Du Heaume, G. J. 1992. IIE Guides to Insects of Importance to Man 2. Thysanoptera. C. R. Betts, ed. International Institute of Entomology, $\mathrm{CAB}$ International, Wallingford, UK.

28. Peters, D. 1998. An updated list of plant species susceptible to tospoviruses. Pages 107-110 in: Recent Progress in Tospovirus and Thrips Research. D. Peters and R. Goldbach, eds. Wageningen, Netherlands.

29. Radford, A. E., Ahles, H. E., and Bell, C. R. 1968. Manual of the vascular flora of the Carolinas. University of North Carolina, Chapel Hill.

30. Sakimura, K. 1962. Frankliniella occidentalis (Thysanoptera: Thripidae), a vector of the tomato spotted wilt virus, with special reference to the color forms. Ann. Entomol. Soc. Am. 55:387-389.

31. Stobbs, L. W., Broadbent, A. B., Allen, W. R., and Stirling, A. L. 1992. Transmission of tomato spotted wilt virus by the western flower thrips to weeds and native plants found in southern Ontario. Plant Dis. 76:23-29.

32. Swallow, W. H. 1985. Group testing for estimating infection rates and probabilities of disease transmission. Phytopathology 75:882889.

33. Toapanta, M., Funderburk, J., Webb, S. Chellemi, D., and Tsai, J. 1996. Abundance of Frankliniella spp. (Thysanoptera:Thripidae) on winter and spring host plants. Environ. Entomol. 25:793-800.

34. Todd, J. W., Culbreath, A. K., and Brown, S. L. 1996. Dynamics of vector populations and progress of spotted wilt disease relative to insecticide use in peanuts. Acta Hortic. 431:483-490.

35. Ullman, D. E. 1996. Thrips and tospoviruses: Advances and future directions. Acta Hortic. 431:310-324

36. Ullman, D. E., Casey, C. A., Whitfield, A. E., Campbell, L. R., Robb, R. L., Medeiros, R. B., German, T. L., and Sherwood, J. L. 1998. Thrips and tospoviruses: Present and future strategies for management. Proc. 1998 Brighton Conf. - Pests Dis. Vol. 2. British Crop Protection Council, Farnham, UK.

37. Wijkamp, I., and Peters, D. 1993. Determination of the medial latent period of two Tospoviruses in Frankliniella occidentalis, using a novel leaf disk assay. Phytopathology 83:986-991. 